\title{
Chapter 11 \\ Paternal Psychological Well-being After Union Dissolution: Does Involved Fatherhood Have a Protective Effect?
}

\author{
Aušra Maslauskaitė and Anja Steinbach
}

\section{Introduction}

While the literature on the extent to which the involvement of a non-resident father can affect a child's developmental outcomes has been expanding (e.g., Elam et al. 2016; Kalmijn 2016; Poortman 2018; Sarkadi et al. 2008), the extent to which a father's engagement level affects his own well-being is an issue that has barely been examined (for an exception, see Waldvogel and Ehlert 2016). The question of whether involved fatherhood has a protective effect on a man's psychological wellbeing after a union dissolution becomes even more relevant if we consider the recent increase in fathers' involvement in childrearing after divorce or separation (Westphal et al. 2014), and the high or growing rates of family dissolution in many countries (Andersson et al. 2017). In addition, numerous studies conducted in Europe and the US have reported that union dissolution has negative effects on the mental health and well-being of men as well as women (e.g., Brockmann and Klein 2004; Williams and Dunne-Bryant 2006). Some studies have suggested that the magnitude of these effects varies significantly across countries: i.e., the negative effects tend to be weaker in "familialistic" than in "individualistic" countries, and in countries where divorce is more common (Kalmijn 2009). Various individual-level factors that contribute to the reduction in men's well-being after separation or divorce have been analyzed (i.e., income, employment, re-partnering) (Wang and Amato 2000). However, the moderating role of fatherhood in the well-being of men after union dissolution is a topic that has, surprisingly, been under-researched (Amato and Dorius 2010).

\footnotetext{
A. Maslauskaitè $(\bowtie)$

Vytautas Magnus University, Kaunas, Lithuania

e-mail: ausra.maslauskaite@vdu.lt
}

\section{A. Steinbach \\ University of Duisburg-Essen, Duisburg, Germany}


In brief, this chapter examines the effects of non-resident fathers' involvement with their children on two psychological well-being outcomes for men: depressive feelings and overall life satisfaction. We analyze the extent to which fathers' involvement levels - measured by frequency of contact, emotional closeness, payment of child support, and co-parenting relationship quality - are associated with their selfreported psychological well-being. By adopting Amato's (2000) divorce-stressadjustment perspective and fatherhood identity theory (Marsiglio et al. 2005), we consider the role of paternal resources and the father's family context, as well as the socio-demographic characteristics of the father and the child.

Our analyses are based on the cross-sectional survey "Fathering after Union Dissolution," which was conducted in Lithuania in $2016(\mathrm{~N}=1500)$ with divorced and separated men who had non-resident children under age 18. Using this database has several advantages. First, the survey has a relatively large sample size and provides detailed measurements on partnership dynamics, the divorce process, the father-child relationship, and father and child characteristics. Moreover, to our knowledge, the dataset is the only one of its kind in the Baltic and the Central and Eastern European countries, where research on the implications of divorce and separation is still in its early stages.

Our study focuses on Lithuania, an EU country characterized by both a high divorce rate and a long tradition of divorce (Maslauskaitè et al. 2015). Divorce expanded rapidly in Lithuania after 1965, following the liberalization of the country's divorce laws. Over the past four decades, the crude divorce rate in Lithuania has fluctuated at around 3.0-3.3 (ibid). Currently, around 35\% of children under age of 15 in Lithuania have experienced parental separation - a share that is among the highest in Europe, and that is comparable to values observed in France (35\%) and Estonia (36\%) (Andersson et al. 2017). The legal framework for divorce in Lithuania does not encourage joint physical custody. After a divorce, the children usually reside with one of the parents, while the non-resident parent receives visitation rights. In $95 \%$ of such cases, the children live with their mother (KudinavičiutèMichailovienè 2013). The visitation order tends to be based on an oral or a written agreement, and the visitation schedule is not legally binding. Generally, a court intervenes in visitation matters only if a mutual agreement is not reached. Joint physical custody is an exceptionally rare arrangement in Lithuania. In a survey of non-resident fathers, $29 \%$ reported meeting with their children at least once a week, and another $37 \%$ said they see their children at least once a month. In the majority of cases, these visits did not include overnight stays (Maslauskaite and Tereškinas 2017). When considering the country context, it should be noted that in Lithuania, discursive and social policy shifts in fatherhood-related issues are occurring that place more weight on paternal involvement in childrearing. Lithuania could also be characterized as a familialistic society, as family ties play a substantial role in the provision of social support in the country (Stankuniene and Maslauskaite 2008).

This chapter contributes to the literature in several ways. First, it adds empirical evidence on the role of paternal involvement in fathers' adjustment to divorce or separation, an issue that currently remains under-researched. Second, it makes a theoretical contribution by building on the divorce-stress-adjustment perspective 
(DSA) (Amato 2000) and the fatherhood identity framework (Marsiglio et al. 2005). Previous studies that examined divorce stress using the coping perspective did not explicitly consider the specifics of non-resident fathers' adjustment to union dissolution. In addition, by integrating paternal involvement and the father-child bond, the interpersonal resources that moderate men's adjustment to divorce can be expanded beyond the kin, friendship, or re-partnering relationships. Third, evidence is presented from an Eastern European region that is covered far less in the literature on divorce outcomes than Western European countries or the United States.

The remainder of this chapter is structured as follows. First, we lay out our theoretical considerations regarding the effects of fathers' involvement with their children on their mental health and well-being. In the next section, we provide an overview of the previous empirical research and develop our hypotheses. After describing our data and methods, we present our bivariate descriptive findings as well as multiple results of linear regression models. We conclude with a discussion of our findings, the limitations of the data, and perspectives for future research.

\section{Theoretical Framework}

Our theoretical framework draws on Amato's (2000) divorce-stress-adjustment perspective (DSA), fatherhood identity theory (Marsiglio and Roy 2013; Marsiglio et al. 2005), and the paternal involvement framework (Pleck 2010b). The DSA perspective is based on stress and coping theories (Hill 1949; McCubbin et al. 1982), and combines various elements of the stress framework. Overall, the DSA perspective suggests that divorce or union dissolution sets in motion numerous stressors, such as the loss of emotional support, conflict with the ex-partner, the transition to sole parenting or the loss of child custody, downward economic mobility, and pressure to move out of the family home. Stressors that the DSA perspective labels as mediators have detrimental effects on the well-being of ex-spouses. However, even though many people who divorce do not fully recover or experience chronic stress for long periods of time, others adjust to being divorced and might even return to the level of well-being they experienced before the dissolution of the union (Amato 2000).

Accordingly, successful forms of adjustment, such as the development of new roles and identities, are indicated by the absence of psychological, behavioral, and health problems. The length of the ex-spouses' processing intervals and their adjustment levels depend on moderating or protective factors "which act as shock absorbers and weaken the links between divorce related events and people's experience of stress" (Amato 2000: 1272). Furthermore, the DSA perspective distinguishes between individual resources, such as coping and social skills; structural resources, like employment and education; and interpersonal resources that come from kin and friendship networks, but also from new partnership relationships. Although the DSA perspective does not explicitly include the non-resident father-child relationship among the moderating factors, it is likely that these relationships help to buffer 
the disruptive life changes linked to divorce or separation, and thus contribute positively to psychological well-being.

Complementing the DSA perspective, the fatherhood identity theory addresses the gender-specific challenges experienced by fathers when adjusting to divorce or separation. As fatherhood identity theory articulates the processes through which a man constructs his role as a father, it helps to explain how the changes in childrearing arrangements that occur in a divorce or separation affect paternal well-being. According to the identity theory, a father's identity is bound up with perpetually processing the meaning of paternal status and role assignment (Marsiglio and Roy 2013). A man creates and recreates his identity as a father through the constant flux of fathering practices that shape his everyday life. The self-crafted dynamic narrative of a father's identity guides his behavior and feelings, and is situated in a proximal context (family, neighborhood environment), but is also maintained through the broader culture and institutions (Marsiglio et al. 2005).

As divorce or separation triggers changes in fathering practices, it can challenge a father's identity. Thus, a partnership break-up reshapes the proximal context of fathering: living in separate households requires a father and his child to establish new routines in their relationship. Since in many cases this happens in a context that is characterized by conflict and disagreement, the stress related to changes in the father's identity might intensify. Potential conflict with the child's mother increases the likelihood of maternal "gatekeeping" (Allen and Hawkins 1999), and might result in additional constraints on a man's participation in childrearing - or, in extreme cases, in the father's withdrawal from having a relationship with his child.

The successful restoration of a man's identity as a father after a divorce or separation is also relevant for his well-being, as there is a culturally synchronous link between masculinity and fatherhood. In the cultural script of normative masculinity, fatherhood is an essential narrative element (Pleck 2010a). In contemporary societies, fatherhood is associated with diverse discursive notions and practices, such as involved fatherhood or a more traditionally oriented role of the father as provider. Nonetheless, fatherhood remains a relevant constituent of masculine identity. Engaging in everyday fathering practices affords men a general sense of meaning and purpose in life, and signals the fulfilment of cultural expectations for masculine behavior. Thus, renegotiating paternal identity after a divorce or separation can be stressful, which should in turn have an impact on a father's psychological well-being.

Identity-related challenges also indirectly affect other life domains, which can, in turn, influence a father's psychological well-being. A desire to comply with the social norms of fatherhood can motivate a man to engage in socially acceptable behavior like working, and to avoid "risky behavior" like binge drinking or using illicit drugs (Edin et al. 2004). As we mentioned above, fatherhood identity theory posits that a father's identity is (re-)created through a wide range of related practices, which could be conceptualized as paternal involvement. The literature has defined paternal involvement as attitudes and behavior that "promote interaction and healthy relationships with the child" (Ihinger-Tallman et al. 1995: 58). Although many attempts to operationalize paternal involvement have been made, one of the most widely used concepts distinguishes between three components (Lamb and 
Tamis-Lemonda 2004; Lamb et al. 1987): accessibility, engagement, and responsibility. Accessibility indicates the time a father spends with his children; engagement refers to the quality of the father-child relationship and activities that contribute to child development (Pleck 2010b); and responsibility refers to the father's role not only in meeting the material needs of and securing resources for his children, but in "taking initiative and monitoring what is needed" (Pleck 2010b: 66).

In discussing the association between the well-being of non-resident fathers and their involvement with their children, it is also important to consider social selection. Having certain personality traits and social characteristics that elevate the risk of separation or divorce can also be associated with a father being less involved with his children and having lower levels of adjustment and well-being. For example, it has been shown that in the U.S. context, men who are less educated have a higher divorce risk (Teachman 2002) and are generally less involved fathers than highly educated men, as they tend to provide less financial support and spend less time with their children (Stykes et al. 2013). There is also evidence that less educated men have lower levels of psychological well-being (Courtenay 2003). Therefore, our findings on the association between paternal involvement and psychological well-being should be interpreted with caution.

\section{Previous Empirical Findings and Hypotheses}

Divorce and Well-being Although several studies have found that divorce has a negative effect on fathers' well-being (e.g., Amato 2010; Williams and DunneBryant 2006), there is also evidence that leaving an unhappy marriage is better than staying in it (Hawkins and Booth 2005; Waite et al. 2009). Additionally, several factors have been found to moderate the association between divorce and wellbeing. A break-up that involves younger children is often associated with very high stress levels, and can lead to secondary stressors like parenting strain, economic strain, and co-parenting issues (Williams and Dunne-Bryant 2006). Meanwhile, higher levels of adjustment to divorce and well-being have been shown to be positively associated with education and employment (for an overview, see Amato 2000, 2010; Härkönen 2014). Adjustment levels may also be influenced by the nature of the previous marriage. For example, ending a high-conflict marriage appears to have less detrimental effects on psychological well-being than ending a low-conflict marriage (Wang and Amato 2000). Re-partnering has been identified as another moderating factor in the divorce adjustment process (Amato 2000, 2010). Embracing new family roles (e.g., as a partner or as a partner/father to new biological or stepchildren) can serve as a source of emotional support and improve a father's psychological well-being (Wang and Amato 2000).

Fatherhood and Well-being Previous empirical findings suggest that the association between fatherhood and well-being is not straightforward. While some studies have found that being a father is positively associated with psychological and 
physical health (Helbig et al. 2006; Knoester and Eggebeen 2006), others have reported that the mental health of fathers suffers, especially during the early parenting period (Evenson and Simon 2005; Giallo et al. 2012). One potential explanation for these inconsistent results is that selection effects on parenthood are at work (Kalucza et al. 2015). Another possible factor is that the effects of fatherhood on a man's well-being depend on his marital and residential context (Eggebeen and Knoester 2001), with a stepfather or non-resident biological father being more likely to have poor outcomes than a co-resident biological father. However, all of those studies compared fathers with childless men, without differentiating between the various contexts of fatherhood.

As we mentioned above, there is plenty of empirical evidence suggesting that children with involved fathers have more positive outcomes (e.g., Choi et al. 2014; Sarkadi et al. 2008). Researchers have also recognized that the quality of the relationship between the non-resident father and his children is more important than the simple frequency of contact (Amato and Gilbreth 1999; Whiteside and Becker 2000). These findings might apply to the well-being of fathers, too. The paper that comes closest to answering this question is by Knoester et al. (2007), who used data from the first two waves of the Fragile Families Study to examine how changes in commitments to fathering in different family contexts are related to changes in fathers' well-being over a 1-year period. They found that changes in fathers' attitudes towards and engagement with their children between birth and 1 year were generally associated with small but significant improvements in their well-being with respect to health, depression, substance abuse, religious conviction, and paid labor; but also that increased paternal engagement was linked to lower work hours, presumably due to time demands (Knoester et al. 2007).

Non-resident Father's Involvement and Well-being The only existing study that relates to our research question examined the association between different contemporary forms of fatherhood (biological fathers, stepfathers, adoptive fathers, and foster fathers) and paternal psychological well-being (chronic stress, life satisfaction, and psychological distress) (Waldvogel and Ehlert 2016). The main finding of this study was that biological fathers who were living with the mother of their children had higher levels of well-being than other types of fathers (such as single, non-resident fathers or stepfathers). Even after controlling for several sociodemographic characteristics, the results indicated that fathers who were separated or divorced had the worst outcomes on multiple dimensions of psychological wellbeing. The findings further suggested that maintaining regular contact with their non-resident children seemed to protect divorced and separated fathers from negative outcomes. However, after controlling for contact frequency, the psychological well-being of separated fathers was still found to be worse than that of other kinds of fathers. The authors argued that one potential explanation for this result is that although most of the separated or divorced fathers had regular contact with their non-resident children, they were significantly less involved in day-to-day childcare activities than fathers in stable families: "Thus, regular contact within the limits of visitation arrangements may not be sufficiently rewarding to compensate for the 
emotional costs of family separation, meaning that these fathers might still feel burdened by their lack of involvement in everyday childcare" (Waldvogel and Ehlert 2016: 12).

A number of studies have shown that there is a growing cultural expectation that non-resident fathers become more involved in their children's lives economically and socially. There is also evidence that over the past few decades, this shift in attitudes has led to a substantial increase in father-child contact after a parental breakup (Amato et al. 2009). Moreover, in addition to having more frequent contact with their non-resident children, it appears that fathers have become more conscientious about paying child support (Amato et al. 2009). Thus, the standards of active fatherhood seem to have risen not only for men who are in a partnership with the mother of their children, but for men who are divorced.

Given the evidence that men with higher educational levels provide more regular support for their children after a parental dissolution than men with less education (Schnor et al. 2017), education is an important overall factor to be considered in the analyses. Likewise, there is evidence that poor fathers are more likely than higherincome fathers to lose contact with their children (Skevik 2006). This could be because poor fathers who live farther away after the parental break-up do not have the resources to stay in contact (Dommermuth 2016), or because poor fathers have fewer resources to spend on their children when they see them. So-called "recreational fatherhood" - i.e., taking children to participate in leisure or "Disneyland" activities, such as going out to restaurants, movies, or sporting events - requires resources that men who are struggling financially do not possess (Amato and Dorius 2010; Stewart 1999).

Similarly, re-partnering and founding a new family with additional children could have an impact on a father's involvement with his children from a previous partnership. However, the results of studies that have examined whether this is the case are not consistent. Some authors have found that re-partnered fathers "swap" their older children for their new children (Manning and Smock 2000), or are less involved with their older children because of the time constraints and financial and emotional demands that come with having two families (Manning et al. 2003; Swiss and Le Bourdais 2009). Others have argued that re-partnering facilitates paternal involvement, either because having a new partner releases a man from household duties, and thus allows him to intensify his commitment to his children (Hetherington 2006); or because it signals a man's attachment to traditional family customs and duties (Cooksey and Craig 1998).

Against this background, the association between custody arrangements and paternal well-being should be taken into account. Compared to other divorced parents, parents with joint physical custody (JPC) often report being more satisfied with their situation (Bergström et al. 2014; Cashmore et al. 2010), feeling less time pressure (Van der Heijden et al. 2016), and having more time for both leisure time activities and labor force participation (Botterman et al. 2015). One study from the U.S. has shown that JPC parents are also in better physical and emotional health than parents with sole physical custody (Melli and Brown 2008). However, another 
study from Belgium found no direct association between custody status and parental subjective well-being (Sodermans et al. 2015).

The divorce-stress-adjustment perspective (Amato 2010) states that adjustment to divorce, as indicated by, for example, the level of psychological well-being, is moderated by interpersonal resources. Following father identity theory, we argue that non-resident father-child relationships constitute an important element of interpersonal resources, and, thus, that the father-child bond plays an essential role in moderating divorce-related stress. Based on the theoretical considerations and previous findings mentioned above, we hypothesize that higher levels of paternal involvement in all three components (accessibility, engagement, and responsibility) contribute positively to the psychological well-being of non-resident fathers (Hypothesis 1). Furthermore, based on the results reported by Waldvogel and Ehlert (2016), we expect to find that out of all the components of paternal involvement, engagement has the clearest positive effect on paternal well-being, because it reflects the qualitative side of the relationship (Hypothesis 2). In addition, we argue that psychological well-being is associated with the interpersonal resources linked to a man's family trajectory after divorce or separation. Accordingly, our next hypothesis states that having a higher level of psychological well-being could be explained by a man's family context after divorce or separation. Therefore, we expect to find that re-partnered fathers are better adjusted than single fathers, and thus have elevated levels of psychological well-being (Hypothesis 3).

\section{Data and Methods}

\section{Data and Analytical Sample}

We used data derived from the cross-sectional survey "Fathering after Union Dissolution," which was conducted in Lithuania in 2016. The primary unit in the sample was a male respondent with non-resident children under the age of 18 from a previous marriage or cohabiting union. The sample was obtained using multistage stratified sampling methods. In the first stage, the sample was stratified by all ten administrative districts in Lithuania, while distinguishing between the largest towns in the district and other urban and rural areas. The size of each stratum was set proportionally to the distribution of the male population aged 25-54. In the second stage, we applied a random sampling procedure. The final sample consisted of 1505 respondents. Face-to-face interviews with the respondents were conducted in their homes using a standardized questionnaire. Since we excluded from these analyses men who had never shared a household with their children, our effective sample included 1225 non-resident fathers who were not the primary custodians of their children.

The survey recorded information on a wide range of themes related to the men's life course events (partnership and fertility histories were recorded on a 
calendar-based information), including information on the divorce process and the post-divorce relationship with the child's mother, the respondents' subjective and psychological well-being, payment of child support, levels and types of father-child contact, father-child relationship characteristics, current partnerships, and sociodemographic and structural well-being indicators. Baltic Survey Ltd. conducted the sampling and fieldwork. Up to the present time, this dataset remains unique, as it contains very detailed information on post-divorce fathers in Lithuania; and is, to our knowledge, the only dataset of its kind in the Baltic and Eastern European countries.

\section{Variables}

We employed two indicators of psychological well-being. First, we measured depressive feelings using the Center for Epidemiological Studies Depression Scale (CES-D 8 scale) (Radloff 1977). The CES-D 8 is a self-reported inventory of seven emotional states indicating depression that the respondent may have experienced during the week before the interview. Each item was measured on a four-point frequency scale with values ranging from one (never or almost never) to four (very often or almost all the time). From these items, we composed an index summary variable. The values ranged from one to 22 , with lower values indicating the absence of depressive feelings. The second dependent variable was general life satisfaction, measured by the Cantril ladder (Cantril 1965) with values between one (complete dissatisfaction with life) and ten (complete satisfaction with life).

Based on our theoretical model, the existing findings, and our hypotheses, we considered three sets of independent variables. The first set included four measures of paternal involvement. (1) We used an indicator of non-resident father and child face-to-face contact frequency in the year preceding the interview. The variable indicated the accessibility component of paternal involvement, and ranged from one (no contact) to six (contact at least once a week). (2) In addition, we considered the father's assessment of the quality of his relationship with the child. This variable approximated the engagement component of paternal involvement. The variable ranged from one to five, with low values indicating poor relationship quality. (3) We also included an indicator on the co-parenting relationship; i.e., the father's subjective perception of the quality of his relationship with the child's mother. The quality of co-parenting was measured on a five-point scale, with higher values indicating higher quality. (4) The last variable on paternal involvement was child support payments. We used a dichotomous variable indicating the payment $(=1)$ or the nonpayment $(=0)$ of child support in the year preceding the interview. The last two variables expressed the responsibility component of paternal involvement.

Following our theoretical model, we also took into account $a$ father's individual resources that might facilitate psychological well-being after separation. First, we used an education variable with three categories: below upper secondary (low, ISCED 0-2), upper secondary (middle, ISECD 3-4), and tertiary (high, ISCED 
6-8). ${ }^{1}$ Next, we included a variable on material living conditions with values ranging from one to five, with low values indicating material deprivation ("I lack money even for food."), and high values indicating material sufficiency ("I can afford all I want."). In addition, we incorporated a variable on the father's family context. Three living situations were distinguished: living with a new partner but without (new) children, living with a new partner and with (new) children (stepchildren or new biological children), and living without a partner (=single).

For our controls, we included several variables. Time is a relevant factor in the adjustment process. Thus, we used a variable that measures time since union dissolution (in years). We also included a variable on divorce conflict, because experiencing a higher level of conflict in the process of divorce might affect a man's levels of adjustment to divorce and post-separation well-being. Divorce conflict was measured on a 10-point scale, with lower values indicating an absence of conflict (=1), and the highest value indicating extensive conflict $(=10)$. Based on the existing evidence, we incorporated additional controls, such as the father's age, the child's age, and the child's sex. If a father had multiple children, we only considered the first child from the dissolved union. However, the majority of the sample (80\%) reported having only one child. Descriptive information on all of the variables is provided in Table 11.1.

We performed multiple stepwise OLS-regression analyses for each of the two paternal psychological well-being outcomes (general life satisfaction and depressive feelings) separately. For each outcome, we included in the first model only the set of independent variables that measure paternal involvement. In the second model, we added the father's resources. In the third model, we added the variable on the father's living situation. The fourth and last model presents the results with all of the control variables included. The results of tests of multicollinearity were satisfactory (statistics for tolerance are above 0.4 and VIF below 2.5). Given the different measurement scales of some explanatory variables, we decided to test the regression models with standardized variables; however, the statistically significant predictors remained the same as those identified in the models with the unstandardized variables.

\section{Results}

Table 11.2 shows the results of the regression analysis with father's general life satisfaction as the outcome variable. Controlling only for paternal involvement (Model 1), we observe that general life satisfaction is significantly associated only with the quality of the father-child relationship and child support payments. Thus, the fathers who reported having positive feelings about the quality of their relationship with a non-resident child also scored higher on general life satisfaction.

${ }^{1}$ ISCED 2011 category five does not exist in the Lithuanian education system. 
Table 11.1 Descriptive sample statistics. Column percent and means (standard errors) ${ }^{\mathrm{a}}$

\begin{tabular}{|c|c|c|}
\hline & Column percent & Means (standard error) \\
\hline \multicolumn{3}{|l|}{ Paternal psychological well-being } \\
\hline Depressive feelings (1-22) & & $3.8(0.09)$ \\
\hline General life satisfaction (1-10) & & $2.1(0.05)$ \\
\hline \multicolumn{3}{|l|}{ Paternal involvement } \\
\hline $\begin{array}{l}\text { Frequency of contact with the child } \\
(1-6)\end{array}$ & & $4.2(0.03)$ \\
\hline $\begin{array}{l}\text { Quality of the relationship with the child } \\
(1-5)\end{array}$ & & $3.5(1.06)$ \\
\hline $\begin{array}{l}\text { Quality of the co-parenting relationship } \\
(1-5)\end{array}$ & & $3.0(0.03)$ \\
\hline Child support payment: yes & 80.0 & \\
\hline \multicolumn{3}{|l|}{ Paternal resources } \\
\hline \multicolumn{3}{|l|}{ Education (ISCED) } \\
\hline Education: low & 46.6 & \\
\hline Education: middle & 31.0 & \\
\hline Education: high & 22.4 & \\
\hline Material living conditions (1-5) & & $2.9(0.02)$ \\
\hline \multicolumn{3}{|l|}{ Paternal living situation } \\
\hline Re-partnered without children & 18.8 & \\
\hline Re-partnered with children & 29.0 & \\
\hline Single & 52.2 & \\
\hline \multicolumn{3}{|l|}{ Controls } \\
\hline Time since union dissolution (years) & & $5.3(0.10)$ \\
\hline Divorce conflict (1-10) & & $6.5(0.06)$ \\
\hline Father's age (years) & & $37.6(0.19)$ \\
\hline Child's age (years) & & $10.6(0.14)$ \\
\hline Child's sex: female & 47.3 & \\
\hline Number of subjects & 1225 & \\
\hline
\end{tabular}

Source: Fathering after Union Dissolution in Lithuania, 2016

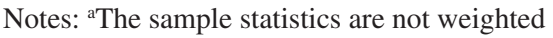

In addition, the fathers who indicated they were paying child support had better psychological outcomes, as measured by general life satisfaction, than the fathers who indicated they were not paying for their child's maintenance. Furthermore, the quality of the co-parenting relationship is shown to be positively linked to the father's general life satisfaction. Contrary to our expectations, we find that the frequency of a father's contact with his child did not contribute to his overall life satisfaction.

In addition to paternal involvement, Model 2 in Table 11.2 includes explanatory variables on paternal resources. The significant effects of paying child support and the quality of co-parenting disappeared after adding variables on education and material living conditions. Thus, it appears that resources mediated the effects of these two dimensions of paternal involvement on a father's general life satisfaction. Having a higher educational level and better material living conditions enabled 


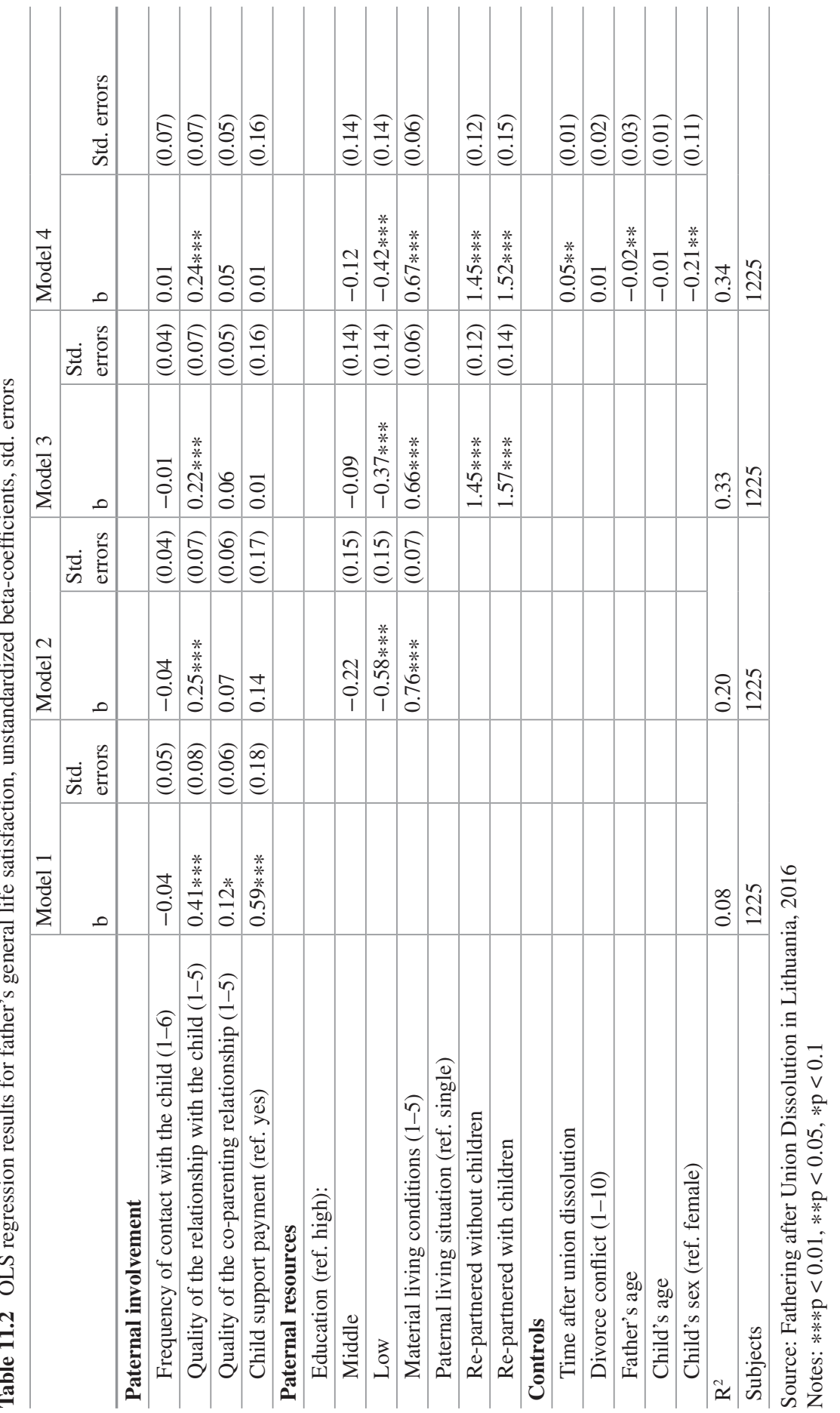


fathers to pay child maintenance and to develop a positive co-parental relationship with the mother, which, in turn, added to their general life satisfaction. However, we observe a persistent positive association between the quality of the relationship with the child and a father's general life satisfaction, even if the effect size decreased after the introduction of resources. The results for education show that fathers with less education reported lower general life satisfaction than more educated fathers, and that there was no difference in the level of general life satisfaction between medium and highly educated men. However, material living conditions are found to be relevant in predicting fathers' general life satisfaction, as fathers who were better off were more likely report being happy with their life.

In Model 3 (Table 11.2), we additionally include the father's living situation. A positive association is shown to remain between the reported quality of a father's relationship with his child and his general life satisfaction. Effects of education and material living conditions are also still detectable, although the effect sizes are only slightly smaller. The results further indicate that re-partnered men with or without (new) children had higher levels of general life satisfaction than men who remained single. Thus, it appears that being single was most detrimental to men's general life satisfaction, while the formation of a partnership with or without new (biological or step-children) was most beneficial to men's general life satisfaction.

The last model (Model 4 in Table 11.2) controls not only for all of the independent variables discussed above, but for factors such as time since the union dissolution, the level of conflict in the divorce process, the father's age, the child's age, and the child's sex. All of the previously identified associations remain, with marginal variation in the effect sizes. Although they are not of primary interest in this chapter, we will briefly discuss the effects of the included control variables. A man's age is shown to be negatively related to his general life satisfaction. A father with a nonresident daughter was more likely to report lower life satisfaction than a father with a son. In contrast to our expectations, the findings indicate that the intensity of conflict in the divorce process did not affect a man's general life satisfaction after a union dissolution.

Table 11.3 presents results for the second dimension of paternal psychological well-being: depressive feelings. As we explained above, this dependent variable measures the frequency of depressive feelings, with higher values indicating more frequent depressive symptoms (in the week before the interview). In the initial model (Model 1), we again include only the four variables on paternal involvement. Two aspects of involvement are shown to be related to a father's well-being. A man who reported having a higher quality relationship with his non-resident child was more likely to score low on depressive feelings. A similar pattern is observed for paying child support. Again, we see no statistically significant effects of contact frequency and the quality of the co-parenting relationship on paternal well-being.

In the next step (Model 2 in Table 11.3), we also consider the father's educational background and material living conditions. The results show that the effects of relationship quality and paying child support persist, but that resources also have an impact on depressive feelings. Separated men with less education were more likely than their highly educated counterparts to report having frequent depressive feelings. Again, we observe no statistically significant difference between men with 


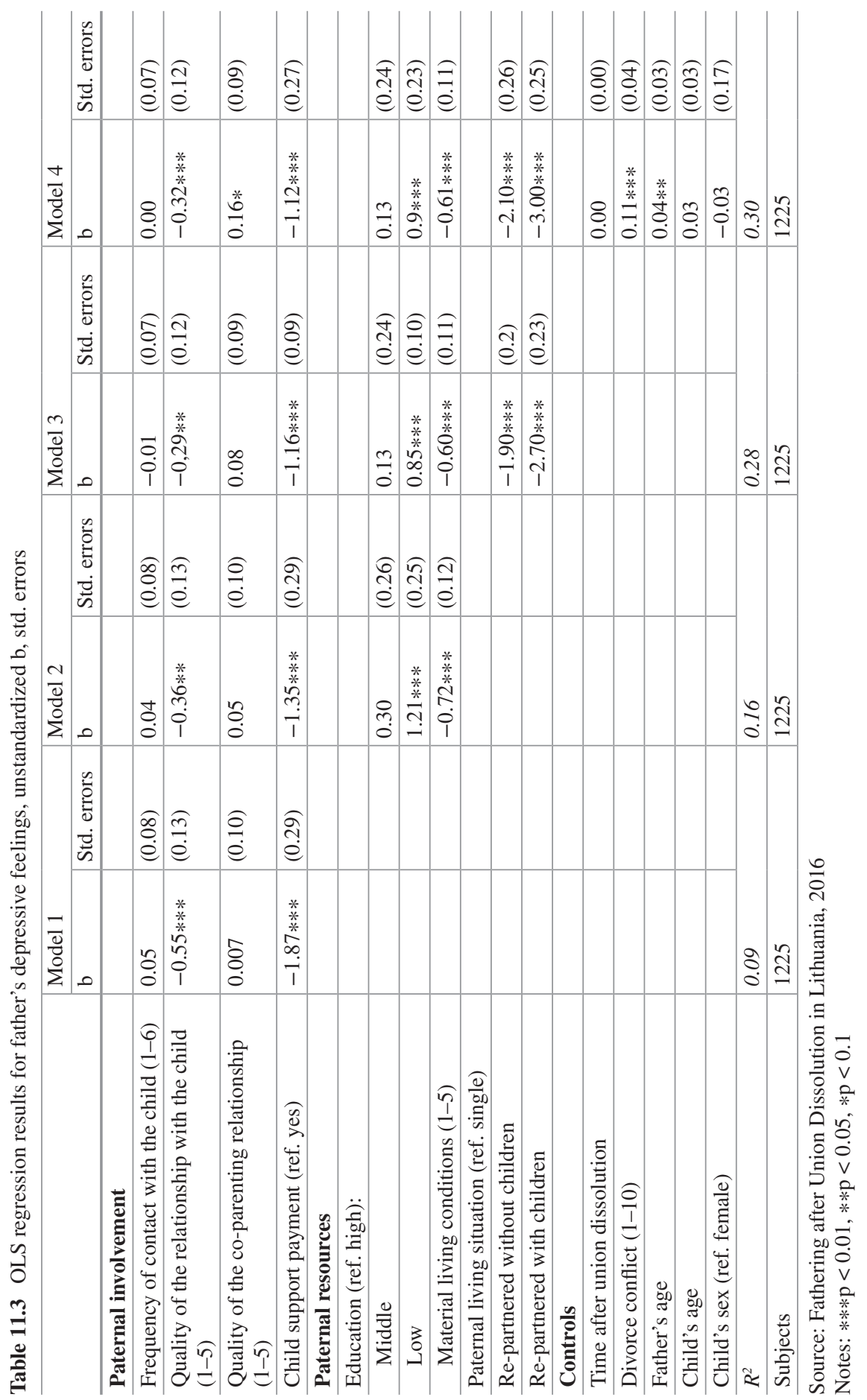


medium and high levels of education. Material living conditions are shown to be inversely associated with depressive feelings; meaning that fathers who described their material conditions as disadvantaged scored higher on this dimension of psychological well-being.

Model 3 in Table 11.3 also considers the father's living situation. Adding this predictor did not significantly change the effects of any related variable on paternal involvement and resources. Men who reported having better quality relationships, a history of paying child support, and materially advantageous living conditions are also shown to have higher well-being; i.e., fewer depressive symptoms. Having less education is found to be positively related to frequently having depressive feelings. Again, as in the case of general life satisfaction, we observe that having a new partnership with or without (biological or step-) children was beneficial to a man's wellbeing. A man who remained single was more likely to report having frequent depressive feelings than a man who was re-partnered. All of the significant associations discussed above remained after we added the control variables in Model 4 (Table 11.3). It is worth mentioning that the age of the father is shown to be positively related to depressive feelings. Of equal interest is the finding that the intensity of the divorce conflict contributes to the model; i.e., that having a high level of conflict during the divorce or separation process was positively associated with having depressive feelings. However, we see no effects on paternal depressive feelings of child-related characteristics or the length of time since the union dissolution.

\section{Conclusion}

The involvement of fathers with their non-resident children after union dissolution is a topic that is receiving increasing attention in the literature on divorced and separated families. For example, studies that examined why some fathers are more involved than others (e.g., Köppen et al. 2018) have shown that this is a policyrelevant issue. Moreover, scholars have been increasingly investigating the impact of paternal involvement on the well-being of children (e.g., Poortman 2018). Nevertheless, the question of the extent to which a father's involvement with his non-resident children affects his own psychological well-being is considered only very rarely, even though the issue of the well-being of parents should be of no less importance. Accordingly, our research question was as follows: Does a father's involvement with his non-resident children protect him psychologically from the adverse effects of union dissolution? In explaining the theoretical association between paternal involvement and psychological well-being, we drew upon the divorce-stress-adjustment perspective (Amato 2000), the fatherhood identity theory (Marsiglio and Roy 2013; Marsiglio et al. 2005), and the paternal involvement framework (Pleck 2010b). In brief, we argued that the successful recreation of the fatherhood identity after a divorce or separation is relevant for a man's well-being because there are very close cultural links between masculinity and fatherhood. 
Involvement with his children can help to recreate fatherhood, and can buffer a father from break-up-related stress.

Our regression results are based on the cross-sectional survey "Fathering after Union Dissolution," which was conducted in 2016 in Lithuania with divorced or separated men who had non-resident children under age 18. As information on two dependent variables for psychological well-being was available, we ran two separate analyses for "depressive feelings" and for "general life satisfaction." Our findings indicated that the quality of a father's relationship with his child was the most important factor in paternal psychological well-being. Even after controlling for the father's resources, living situation, and other socio-demographic characteristics, we found clear evidence that the quality of this relationship had a negative impact on a father's depressive feelings and a positive impact on his general life satisfaction. Thus, our second hypothesis has been confirmed. We also found that paying child support was associated with a reduction in depressive feelings. Yet contrary to our expectations, the results indicated that neither frequent contact with the non-resident child nor the quality of the co-parenting relationship with the mother played a role in either the frequency of depressive feelings or general life satisfaction for the father. Thus, our initial hypothesis was only partially supported. However, our third hypothesis was confirmed, as we found evidence that re-partnering had a positive impact on paternal psychological well-being.

As every study suffers from some limitations, we should mention that, first, the cross-sectional design of our data did not allow us to control for the father's social characteristics prior to the union dissolution. However, in order to partially control for selection, we included in the analysis some social indicators that were likely the same before and after the union dissolution. Second, we examined only two dimensions of psychological well-being (depressive feelings and general life satisfaction), even though other dimensions (e.g., loneliness) might have been studied as well. Further research should be able to clarify these issues.

Although researchers are increasingly interested in exploring the effects of paternal involvement on the well-being of children, they appear to be less interested in investigating the effects of this involvement on the well-being of fathers themselves. This represents a large research gap, given that parental health and well-being are as important as the well-being of children. It should also be emphasized that the wellbeing of parents is linked to the well-being of their children. Thus, it is clear that a society needs healthy and functioning adults, as well as children. Our results reveal that a father's involvement with his children can greatly affect his psychological well-being. Again, however, it must be stressed that for both children and their fathers, the quality of the father-child relationship has a greater effect on well-being than the quantity of contact.

Acknowledgments This research has received funding from European Social Fund (project No. 09.3.3-LMT-K-712-01-0020) under grant agreement with the Research Council of Lithuania (LMTLT). 


\section{References}

Allen, S. M., \& Hawkins, A. J. (1999). Maternal gatekeeping: Mothers' beliefs and behaviors that inhibit greater father involvement in family work. Journal of Marriage and Family, 61(1), 199-212. https://doi.org/10.2307/353894.

Amato, P. R. (2000). The consequences of divorce for adults and children. Journal of Marriage and Family, 62(4), 1269-1287. https://doi.org/10.1111/j.1741-3737.2000.01269.x.

Amato, P. R. (2010). Research on divorce: Continuing trends and new developments. Journal of Marriage and Family, 72(3), 650-666. https://doi.org/10.1111/j.1741-3737.2010.00723.x.

Amato, P. R., \& Dorius, C. (2010). Fathers, children, and divorce. In M. E. Lamb (Ed.), The role of the father in child development (pp. 177-200). Hoboken: Wiley.

Amato, P. R., \& Gilbreth, J. G. (1999). Nonresident fathers and children's well-being: A metaanalysis. Journal of Marriage and the Family, 61(3), 557-573. https://doi.org/10.2307/353560.

Amato, P. R., Meyers, C. E., \& Emery, R. E. (2009). Changes in nonresident fatherchild contact from 1976 to 2002. Family Relations, 58(1), 41-53. https://doi. org/10.1111/j.1741-3729.2008.00533.x.

Andersson, G., Thomson, E., \& Duntava, A. (2017). Life-table representations of family dynamics in the 21st century. Demographic Research, 37(35), 1081-1230. https://doi.org/10.4054/ DemRes.2017.37.35.

Bergström, M., Fransson, E., Hjern, A., Köhler, L., \& Wallby, T. (2014). Mental health in Swedish children living in joint physical custody and their parents' life satisfaction: A crosssectional study. Scandinavian Journal of Psychology, 55(5), 433-439. https://doi.org/10.1111/ sjop.12148.

Botterman, S., Sodermans, A. K., \& Matthijs, K. (2015). The social life of divorced parents. Do custody arrangements make a difference in divorced parents' social participation and contacts? Leisure Studies, 34(4), 487-500. https://doi.org/10.1080/02614367.2014.938768.

Brockmann, H., \& Klein, T. (2004). Love and death in Germany: The marital biography and its effect on mortality. Journal of Marriage and Family, 66(3), 567-581. https://doi. org/10.1111/j.0022-2445.2004.00038.x.

Cantril, H. (1965). The pattern of human concerns. New Brunswick: Rutgers University Press.

Cashmore, J., Parkinson, P., Weston, R., Patulny, R., Redmond, G., Qu, L., et al. (2010). Shared care parenting arrangements since the 2006 family law reforms: Report to the Australian government attorney-general's department Sydney. Social Policy Research Centre, University of New South Wales. https://www.ag.gov.au/FamiliesAndMarriage/Families/FamilyLawSystem/ Documents/SharedCareParenting Arrangementssincethe2006FamilyLawreformsreport.pdf. Accessed 30 June 2019.

Choi, J. K., Palmer, R. J., \& Pyun, H. S. (2014). Three measures of non-resident fathers' involvement, maternal parenting, and child development in low-income single-mother families. Child \& Family Social Work, 19(3), 282-291. https://doi.org/10.1111/cfs.12000.

Cooksey, E. C., \& Craig, P. H. (1998). Parenting from a distance: The effects of paternal characteristics on contact between nonresidential fathers and their children. Demography, 35(2), 187-200. https://doi.org/10.2307/3004051.

Courtenay, W. H. (2003). Key determinants of the health and well-being of men and boys. International Journal of Men's Health, 2(1), 1-30. http://menshealth.org/code/KEY-DTR.pdf. Accessed 30 June 2019.

Dommermuth, L. (2016). Children as family commuters. The geographical distance between nonresident parents and children in Norway. Discussion Papers Statistics Norway, 841(5). https:// www.ssb.no/en/forskning/discussion-papers/_attachment/267802. Accessed 30 June 2019.

Edin, K., Nelson, T. J., \& Paranal, R. (2004). Fatherhood and incarceration as potential turning points in the criminal careers of unskilled men. In M. Pattillo, D. Weiman, \& B. Western (Eds.), Imprisoning America (pp. 46-75). New York: Russell Sage Foundation.

Eggebeen, D. J., \& Knoester, C. (2001). Does fatherhood matter for men? Journal of Marriage and Family, 63(2), 381-393. https://doi.org/10.1111/j.1741-3737.2001.00381.x. 
Elam, K. K., Sandler, I., Wolchik, S., \& Tein, J.-Y. (2016). Non-residential father-child involvement, interparental conflict, and mental health of children following divorce: A personfocused approach. Journal of Youth and Adolescence, 45(3), 581-593. https://doi.org/10.1007/ s10964-015-0399-5.

Evenson, R. J., \& Simon, R. W. (2005). Clarifying the relationship between parenthood and depression. Journal of Health and Social Behavior, 46(4), 341-358. https://doi. org/10.1177/002214650504600403.

Giallo, R., D’Esposito, F., Christensen, D., Mensah, F., Cooklin, A., Wade, C., et al. (2012). Father mental health during the early parenting period: Results of an Australian population based longitudinal study. Social Psychiatry and Psychiatric Epidemiology, 47(12), 1907-1916. https:// doi.org/10.1007/s00127-012-0510-0.

Härkönen, J. (2014). Divorce: Trends, patterns, causes, and consequences. In J. Treas, J. Scott, \& M. Richards (Eds.), The Wiley Blackwell Companion to the sociology of families (pp. 303-322). Chichester: Wiley.

Hawkins, D. N., \& Booth, A. (2005). Unhappily ever after: Effects of long-term, low-quality marriages on well-being. Social Forces, 84(1), 451-471. https://doi.org/10.1353/sof.2005.0103.

Helbig, S., Lampert, T., Klose, M., \& Jacobi, F. (2006). Is parenthood associated with mental health? Social Psychiatry and Psychiatric Epidemiology, 41(11), 889-896. https://doi. org/10.1007/s00127-006-0113-8.

Hetherington, E. M. (2006). The influence of conflict, marital problem solving, and parenting on children's adjustment in nondivorced, divorced and remarried families. In A. Clarke-Stewart \& J. Dunn (Eds.), Families count: Effects on child and adolescent development (pp. 203-237). New York: Cambridge University Press.

Hill, R. (1949). Families under stress: Adjustment to the crises of war separation and reunion. New York: Harper \& Brothers.

Ihinger-Tallman, M., Pasley, K., \& Buehler, C. L. (1995). Developing a middle-range theory of father involvement post-divorce. In W. Marsiglio (Ed.), Fatherhood: Contemporary theory, research, and social policy (pp. 57-77). Thousand Oaks: Sage.

Kalmijn, M. (2009). Country differences in the effects of divorce on well-being: The role of norms, support, and selectivity. European Sociological Review, 26(4), 475-490. https://doi. org/10.1093/esr/jcp035.

Kalmijn, M. (2016). Father-child contact, interparental conflict, and depressive symptoms among children of divorced parents. European Sociological Review, 32(1), 68-80. https://doi. org/10.1093/esr/jcv095.

Kalucza, S., Hammarström, A., \& Nilsson, K. (2015). Mental health and parenthood - A longitudinal study of the relationship between self-reported mental health and parenthood. Health Sociology Review, 24(3), 283-296. https://doi.org/10.1080/14461242.2015.1051079.

Knoester, C., \& Eggebeen, D. J. (2006). The effects of the transition to parenthood and subsequent children on men's well-being and social participation. Journal of Family Issues, 27(11), 1532-1560. https://doi.org/10.1177/0192513X06290802.

Knoester, C., Petts, R. J., \& Eggebeen, D. J. (2007). Commitments to fathering and the well-being and social participation of new, disadvantaged fathers. Journal of Marriage and Family, 69(4), 991-1004. https://doi.org/10.1111/j.1741-3737.2007.00426.x.

Köppen, K., Kreyenfeld, M., \& Trappe, H. (2018). Loose ties? Determinants of father-child contact after separation in Germany. Journal of Marriage and Family, 80(5), 1163-1175. https:// doi.org/10.1111/jomf.12504.

Kudinavičiūtè-Michailovienè, I. (2013). Santuokos nutraukimo teisinès pasekmès ir jų išsprendimo problematika ištuokos bylose. In E. Tamošiūnienè \& I. Kudinavičiūtè-Michailovienè (Eds.), Šeimos bylu nagrinėjimo ir teismo sprendimu vykdymo ypatumai (pp. 59-103). Vilnius: MRU.

Lamb, M. E., \& Tamis-Lemonda, C. S. (2004). The role of the father: An introduction. In M. E. Lamb (Ed.), The role of the father in child development (pp. 1-31). Hoboken: Wiley. 
Lamb, M. E., Pleck, J. H., Charnov, E. L., \& Levin, J. A. (1987). A biosocial perspective on paternal behavior and involvement. In J. B. Lancaster, J. Altmann, A. S. Rossi, \& L. R. Sherrod (Eds.), Parenting across the lifespan: Biosocal dimensions (pp. 111-142). New York: De Gruyter.

Manning, W. D., \& Smock, P. J. (2000). "Swapping" families: Serial parenting and economic support for children. Journal of Marriage and the Family, 62(1), 111-122. https://doi. org/10.1111/j.1741-3737.2000.00111.x.

Manning, W. D., Stewart, S. D., \& Smock, P. J. (2003). The complexity of father's parenting responsibilities and involvement with nonresident children. Journal of Family Issues, 24(5), 645-667. https://doi.org/10.1177/0192513X03252573.

Marsiglio, W., \& Roy, K. (2013). Fathers' nurturance of children over the life course. In G. Peterson \& K. Bush (Eds.), Handbook of marriage and the family (pp. 353-376). Boston: Springer.

Marsiglio, W., Roy, K., \& Fox, G. L. (2005). Situated fathering: A spatially sensitive and social approach. In W. Marsiglio, K. Roy, \& G. L. Fox (Eds.), Situated fathering: A focus on physical and social spaces (pp. 3-26). Lanham: Rowan Littlefield Publishers.

Maslauskaitè, A., \& Tereškinas, A. (2017). Involving nonresident Lithuanian fathers in childrearing: The negative impact of income inequalities and sociolegal policies. Men and Masculinities, 20(5), 609-629. https://doi.org/10.1177/1097184X17727798.

Maslauskaite, A., Jasilioniene, A., Jasilionis, D., Stankuniene, V., \& Shkolnikov, V. M. (2015). Socio-economic determinants of divorce in Lithuania: Evidence from register-based census-linked data. Demographic Research, 33(30), 871-908. https://doi.org/10.4054/ DemRes.2015.33.30.

McCubbin, H. I., Cauble, A. E., \& Patterson, J. M. (1982). Family stress, coping, and social support. Springfield: Thomas.

Melli, M. S., \& Brown, P. R. (2008). Exploring a new family form. The shared time family. International Journal of Law, Policy and the Family, 22(2), 231-269. https://doi.org/10.1093/ lawfam/ebn002.

Pleck, J. H. (2010a). Fatherhood and masculinity. In M. E. Lamb (Ed.), The role of the father in child development (pp. 27-57). Hoboken: Wiley.

Pleck, J. H. (2010b). Paternal involvement: Revised conceptualization and theoretical linkages with child outcomes. In M. E. Lamb (Ed.), The role of the father in child development (pp. 58-93). Hoboken: Wiley.

Poortman, A.-R. (2018). Postdivorce parent-child contact and child well-being: The importance of predivorce parental involvement. Journal of Marriage and Family, 80(3), 671-683. https://doi. org/10.1111/jomf.12474.

Radloff, L. S. (1977). The CES-D scale: A self-report depression scale for research in the general population. Applied Psychological Measurement, 1(3), 385-401. https://doi. org/10.1177/014662167700100306.

Sarkadi, A., Kristiansson, R., Oberklaid, F., \& Bremberg, S. (2008). Fathers' involvement and children's developmental outcomes: A systematic review of longitudinal studies. Acta Paediatrica, 97(2), 153-158. https://doi.org/10.1111/j.1651-2227.2007.00572.x.

Schnor, C., Vanassche, S., \& Van Bavel, J. (2017). Stepfather or biological father? Educationspecific pathways of postdivorce fatherhood. Demographic Research, 37(51), 1659-1694. https://doi.org/10.4054/DemRes.2017.37.51.

Skevik, A. (2006). 'Absent fathers' or 'reorganized families'? Variations in father-child contact after parental break-up in Norway. The Sociological Review, 54(1), 114-132. https://doi. org/10.1111/j.1467-954X.2006.00604.x.

Sodermans, A. K., Botterman, S., Havermans, N., \& Matthijs, K. (2015). Involved fathers, liberated mothers? Joint physical custody, and the subjective well-being of divorced parents. Social Indicators Research, 122(1), 257-277. https://doi.org/10.1007/s11205-014-0676-9.

Stankuniene, V., \& Maslauskaite, A. (2008). Family transformations in the post-communist countries: Attitudes toward changes. In C. Höhn, D. Avramov, \& I. E. Kotowska (Eds.), People, population change and policies (pp. 113-138). Wiesbaden: Springer. 
Stewart, S. D. (1999). Disneyland dads, Disneyland moms? How nonresident parents spend time with absent children. Journal of Family Issues, 20(4), 539-556. https://doi. org/10.1177/019251399020004006.

Stykes, J. B., Manning, W. D., \& Brown, S. L. (2013). Nonresident fathers and formal child support: Evidence from the CPS, the NSFG, and the SIPP. Demographic Research, 29(46), 1299-1330. https://doi.org/10.4054/DemRes.2013.29.46.

Swiss, L., \& Le Bourdais, C. (2009). Father-child contact after separation: The influence of living arrangements. Journal of Family Issues, 50(5), 623-652. https://doi.org/10.117 7/0192513X08331023.

Teachman, J. D. (2002). Stability across cohorts in divorce risk factors. Demography, 39(2), 331-351. https://doi.org/10.1353/dem.2002.0019.

Van der Heijden, F., Poortman, A.-R., \& Van der Lippe, T. (2016). Children's postdivorce residence arrangements and parental experienced time pressure. Journal of Marriage and Family, 78(2), 468-481. https://doi.org/10.1111/jomf.12283.

Waite, L. J., Luo, Y., \& Lewin, A. C. (2009). Marital happiness and marital stability: Consequences for psychological well-being. Social Science Research, 38(1), 201-212. https://doi. org/10.1016/j.ssresearch.2008.07.001.

Waldvogel, P., \& Ehlert, U. (2016). Contemporary fatherhood and its consequences for paternal psychological well-being - A cross-sectional study of fathers in central Europe. Frontiers in Public Health, 4, 199. https://doi.org/10.3389/fpubh.2016.00199.

Wang, H., \& Amato, P. R. (2000). Predictors of divorce adjustment: Stressors, resources, and definitions. Journal of Marriage and Family, 62(3), 655-668. https://doi. org/10.1111/j.1741-3737.2000.00655.x.

Westphal, S. K., Poortman, A.-R., \& Van der Lippe, T. (2014). Non-resident father-child contact across divorce cohorts: The role of father involvement during marriage. European Sociological Review, 30(4), 444-456. https://doi.org/10.1093/esr/jcu050.

Whiteside, M. F., \& Becker, B. J. (2000). Parental factors and the young child's postdivorce adjustment: A meta-analysis with implications for parenting arrangements. Journal of Family Psychology, 14(1), 5-26. https://doi.org/10.1037//0893-3200.14.1.5.

Williams, K., \& Dunne-Bryant, A. (2006). Divorce and adult psychological well-being: Clarifying the role of gender and child age. Journal of Marriage and Family, 68(5), 1178-1196. https:// doi.org/10.1111/j.1741-3737.2006.00322.x.

Open Access This chapter is licensed under the terms of the Creative Commons Attribution 4.0 International License (http://creativecommons.org/licenses/by/4.0/), which permits use, sharing, adaptation, distribution and reproduction in any medium or format, as long as you give appropriate credit to the original author(s) and the source, provide a link to the Creative Commons license and indicate if changes were made.

The images or other third party material in this chapter are included in the chapter's Creative Commons license, unless indicated otherwise in a credit line to the material. If material is not included in the chapter's Creative Commons license and your intended use is not permitted by statutory regulation or exceeds the permitted use, you will need to obtain permission directly from the copyright holder. 